\title{
Effects of dietary supplementation of L-carnitine on performance, carcass and meat characteristics of quails
}

\author{
S. Sarica ${ }^{1 \#}$, M. Corduk ${ }^{2}$, U. Ensoy ${ }^{3}$, H. Basmacioglu ${ }^{4}$ and U. Karatas ${ }^{1}$ \\ ${ }^{1}$ Department of Animal Science, Faculty of Agriculture, University of Gaziosmanpasa, 60240 Tokat, Turkey \\ ${ }^{2}$ Department of Animal Science, Faculty of Agriculture, University of Ankara, 06110 Ankara, Turkey \\ ${ }^{3}$ Department of Food Engineering, Faculty of Agriculture, University of Gaziosmanpasa, 60240 Tokat, Turkey \\ ${ }^{4}$ Department of Animal Science, Faculty of Agriculture, University of Ege, 35040 Izmir, Turkey
}

\begin{abstract}
The present study was conducted to determine the effects of feeding diets containing two levels of metabolizable energy (12.13 or $11.72 \mathrm{MJ} \mathrm{ME} / \mathrm{kg}$ ) and two different fat sources (sunflower- and fish-oil) with or without supplemental L-carnitine $(0$ or $50 \mathrm{mg} / \mathrm{kg}$ diet $)$ on growth performance and carcass and meat characteristics of Japanese quails. Two hundred and forty day-old male quail chicks were randomly assigned to eight treatment groups, each subdivided into three replicates of 10 chicks. The chicks were raised from hatch until 5 wks of age. Feeding the diet containing $12.13 \mathrm{MJ} \mathrm{ME} / \mathrm{kg}$ increases body weight and body weight gain significantly, and improved the feed conversion ratio above that of the lower energy diet. Feed intakes of the birds were unaffected by treatments. The cold carcass yield of quails fed the diet containing sunflower oil was significantly higher than those receiving the diets containing fish oil. After 35 days of feeding the diet containing the standard energy level (12.13 MJ ME/kg) the thigh yield of the birds was significantly higher than that of the chicks on the lower energy diet. Dietary treatments did not affect $\mathrm{pH}$ values of edible meat in the quails. Feeding diets containing sunflower oil and L-carnitine significantly decreased malonaldehyde (MA) amounts in the edible meat. The crude protein content of the edible meat fraction was significantly higher when the dietary energy level was decreased from 12.13 to $11.72 \mathrm{MJ}$ $\mathrm{ME} / \mathrm{kg}$ diet. Decreasing dietary energy levels significantly decreased the "L" (lightness) and "b" values (less yellow) of the meat, while dietary L-carnitine supplementation resulted in a significant increase in "L" value. The total edible meat of the quails on the diets containing fish oil had a higher "a" value (more red) than the quails receiving sunflower oil in their diets. It was concluded that additional studies are required to clarify the role of dietary L-carnitine in the oxidation of long-chain fatty acids, its antioxidant properties and its importance in energy metabolism in Japanese quails.
\end{abstract}

Keywords: L-carnitine, metabolizable energy, fat sources, carcass quality, shelflife of edible meat

" Corresponding author. E-mail: senaysarica2002@yahoo.com

\section{Introduction}

L-carnitine ( $\beta-\mathrm{OH}-\gamma-\mathrm{N}$-trimethylaminobutyric acid) is a water-soluble quaternary amine that occurs naturally in microorganisms, plants and animals (Bremer, 1983). Its concentration in animals varies widely according to species, tissue type and nutritional status of the animal (Rabie et al., 1997a; b). L-carnitine is biosynthesised in the kidneys and liver from lysine and methionine in the presence of ferrous ions and three vitamins, viz. ascorbate, niacin and pyridoxine (Bieber, 1988; Rebouche, 1991; Leibetseder, 1995). Cereal grains and their by-products generally contain very little L-carnitine compared to feedstuffs of animal origin (Baumgartner \& Blum, 1993). However, these plant-based feedstuffs usually constitute the major portion of poultry diets, with the concomitant potential deficiency of carnitine in the diet.

The major metabolic role of L-carnitine is in facilitating the transport of long-chain fatty acids across the inner mitochondrial membrane for $\beta$-oxidation. It also facilitates the removal from mitochondria of shortand medium-chain fatty acids that accumulate as a result of normal and abnormal metabolism (Bremer, 1983; Borum, 1987; Rebouche, 1992; Mast et al., 2000; Matalliotakis et al., 2000; Harmeyer, 2002; Kita et al., 2002; Kidd et al., 2005). Thus, dietary L-carnitine supplementation promotes the $\beta$-oxidation of these fatty acids to generate adenosine triphosphate (ATP) energy and improves energy utilisation and therefore body weight gain and feed efficiency, especially in young animals where synthesis is insufficient to meet endogenous requirements (Gropp et al., 1994; Janssens et al., 2000; Neuman et al., 2002). 
Feeding diets with supplemental fat to poultry can have distinct economic advantages by providing increased energy levels at a lower cost. This is becoming a general practice in poultry production (LopezBote et al., 1997; Russell et al., 2003). Fats added to the diet of fast growing broilers are generally rich in polyunsaturated fatty acids (PUFAs) (Lauridsen et al., 1997). Oils rich in PUFAs have a higher metabolizable energy (ME) than animal fats because PUFAs are better digested than saturated fatty acids (SFA) (Blanch et al., 1995). Increasing the PUFAs content of poultry diets increases the proportion of unsaturated fatty acids in meat and other edible parts. Since lipid oxidation is a major problem in products enriched with n-3 PUFAs, it can be a primary causes of quality deterioration in meat and meat products. It can result in the production of off-flavours and odours, loss of pigment, loss of PUFAs and fat-soluble vitamins, increased drip losses and lower consumer acceptability (Cherian et al., 1996; Jensen et al., 1998; Lawlor et al., 1999; 2003; O'Sullivan et al., 2004b). However, previous studies have indicated that lipid oxidation in poultry products enriched in PUFAs can be prevented by dietary antioxidants (O'Sullivan et al., 2004a).

L-carnitine has antioxidant properties. It functions by reducing the availability of lipids for peroxidation by transporting fatty acids into the mitochondria for $\beta$-oxidation to generate ATP energy (Matalliotakis et al., 2000; Neuman et al., 2002; Rani \& Panneerselvam, 2002). This reduces the amount of lipids available for peroxidation (Kalaiselvi \& Panneerselvam, 1998). Furthermore, L-carnitine, through its antioxidant properties, has been shown to increase the activity and levels of antioxidant enzymes such as superoxide dismutase and glutathione peroxidase in the plasma of poultry (Neuman et al., 2002).

The number of studies on the effect of L-carnitine supplementation of quail diets is limited. Arslan et al. (2004) and Sarica et al. (2005) reported that dietary L-carnitine supplementation did not influence growth performance and carcass traits in quails significantly. Little research has been done to determine whether dietary L-carnitine supplementation can influence the performance, abdominal fat content, internal organ weights and carcass composition of broiler chickens fed diets containing different dietary ME or fat levels, or different dietary fat sources (Cartwright, 1986; Barker \& Sell, 1994; Rabie \& Szilagyi, 1998).

The aim of the present study was to determine the effects of feeding diets with two levels of ME and two sources of fat rich in long-chain PUFAs with or without supplemental L-carnitine on growth performance, and carcass and meat characteristics of Japanese quails.

\section{Materials and Methods}

Two hundred and forty day-old male Japanese quail chicks (Coturnix coturnix japonica) obtained from a commercial hatchery were wing-banded, weighed and randomly assigned to eight groups, each of which was subdivided into three replicates of 10 chicks. From hatch until 5 wks of age the chicks were kept under uniform environmental conditions in wire cages equipped with nipple drinkers. Temperature was kept at $32{ }^{\circ} \mathrm{C}$ for the first week, $28^{\circ} \mathrm{C}$ for the second week and $21{ }^{\circ} \mathrm{C}$ thereafter. A continuous lighting program was provided during the experiment. In a $2 \times 2 \times 2$ factorial arrangement, the chicks were fed isonitrogenous diets containing two energy levels (a standard energy level of $12.13 \mathrm{MJ} \mathrm{ME} / \mathrm{kg}$ or a lower level of $11.72 \mathrm{MJ}$ $\mathrm{ME} / \mathrm{kg}$ ) and two different sources of fat (at $10 \mathrm{~g} / \mathrm{kg}$ ) rich in long-chain PUFAs (sunflower- or fish-oil) with or without supplemental L-carnitine ( 0 or $50 \mathrm{mg} / \mathrm{kg}$ diet). L-carnitine was in the form of Carniking (LONZA Ltd., Basel, Switzerland). The basal diets contained 8.43, 8.70, 8.42 and $8.59 \mathrm{mg}$ L-carnitine/kg, respectively. The calculation of the L-carnitine content of these basal diets was based on the L-carnitine content in the ingredients used (Harmeyer et al., 1998). The composition and the calculated nutrient content of the experimental diets are presented in Table 1 . The experimental diets were designed as:

Diet I: Containing 12.13 MJ ME/kg and sunflower oil (SO) without L-carnitine ( $0 \mathrm{mg} / \mathrm{kg}$ diet);

Diet II: Containing 12.13 MJ ME/kg and SO with L-carnitine (50 mg/kg diet);

Diet III: Containing 11.72 MJ ME/kg and SO without L-carnitine (0 mg/kg diet);

Diet IV: Containing 11.72 MJ ME/ $/ \mathrm{kg}$ and SO with L-carnitine (50 mg/kg diet);

Diet V: Containing 12.13 MJ ME/kg and fish oil (FO) without L-carnitine ( $0 \mathrm{mg} / \mathrm{kg}$ diet);

Diet VI: Containing 12.13 MJ ME/kg and FO with L-carnitine (50 mg/kg diet);

Diet VII: Containing 11.72 MJ ME/kg and FO without L-carnitine $(0 \mathrm{mg} / \mathrm{kg}$ diet $)$;

Diet VIII: Containing 11.72 MJ ME/kg and FO with L-carnitine (50 mg/kg diet). 
Prior to diet formulation, feed ingredients were analyzed for crude protein $(\mathrm{N} \times 6.25, \mathrm{CP})$, crude fat, starch and total sugar content, according to the methods of the AOAC (1984). Metabolizable energy of feed ingredients was calculated based on analyzed values of the ingredients (WPSA, 1989). Except for energy level, all diets were formulated to meet the minimum nutrient requirements of Japanese quails (NRC, 1994). The birds were fed a Japanese quail starter-grower diet from hatch to 5 wks of age. The experimental diets in mash form and drinking water were provided ad libitum. Sunflower oil was supplied by Orucoglu oil industry (Afyon, Turkey) and fish oil (Atlantic Salmon) by Camlibel Feed Industry (Izmir, Turkey). This study was conducted according to the guidelines of the Institutional Animal Care and Use Committee.

During the $35 \mathrm{~d}$ experimental period, the performance of the quails was evaluated by recording body weight gain, feed intake and feed conversion ratio. Individual body weights of quails were recorded at weekly intervals throughout the study. Feed intake for each of the replicate groups of each treatment was also recorded on a weekly basis. Feed conversion ratio was calculated weekly, as the amount of feed consumed per unit of body weight gain.

At the end of the experiment, 12 birds whose body weights were similar to the group average were selected from each treatment group and a total of 96 birds were slaughtered by severing the branchial vein. The carcasses were immediately plucked, processed (removal of head and feet), eviscerated (removal of gastrointestinal tract), weighed and then chilled overnight in a refrigerator $\left(+4{ }^{\circ} \mathrm{C}\right)$. Measurements of carcass yield and carcass characteristics were done on the carcasses. Measurements included hot and cold carcass yields, carcass components (weights of eviscerated carcass, total edible parts, breast yield including bones, thigh plus drumstick including bones, breast meat yield and thigh plus drumstick meat yield, weights of some internal organs), abdominal fat content (as an absolute weight) and chemical composition of edible meat of quails (in terms of dry matter (DM), CP and ether extract contents of breast plus thigh meat). From one side of the breast and one thigh plus drumstick of each quail, meat (with skin) was excised and weighed separately. Edible parts of carcasses selected for nutrients analyses were homogenized using a blender with horizontal blades. Samples were frozen and stored in a freezer at $-20^{\circ} \mathrm{C}$ until further analyses. The carcasses were analyzed for DM, CP and crude fat according to the AOAC (1984). Fat was extracted with ethyl ether using a Soxhlet apparatus. The weights of some internal organs (heart, liver and gizzard) were measured individually. The weights of these internal organs were expressed as an absolute weight. The hot and cold carcass yields were calculated as a percentage of the preslaughter body weight of the quails.

The colour of the meat after slaughtering was measured using a Minolta Chromameter Model CR-300 (Minolta Camera Co., Chuo-Ku, Osaka 541, Japan), with "L", "a" and "b" values. Higher "L" values mean lighter intensity, higher "a" values mean more redness and higher "b" values indicate more yellowness. The $\mathrm{pH}$ value of meat samples was determined after slaughter. The $\mathrm{pH}$ was determined by blending a $10 \mathrm{~g}$ sample in $100 \mathrm{~mL}$ distilled water for one minute, and $\mathrm{pH}$ was measured using a $\mathrm{pH}$ meter (Model Inolab $\mathrm{pH}$ level-1) (Ensoy et al., 2004).

An additional 96 birds were selected and slaughtered to determine the extent of lipid oxidation. Individual carcasses were placed in a sterile polypropylene bag and stored in a non-illuminated refrigerated cabinet overnight at $+4{ }^{\circ} \mathrm{C}$. After that the carcasses were trimmed to obtain the breast and thigh meat by removing skin, bones and connective tissue. These deboned breasts and thighs were ground through $5 \mathrm{~mm}$ plates using a domestic rust-free steel meat mincer. The ground meat samples were wrapped in aluminum foil and stored at $-18{ }^{\circ} \mathrm{C}$ for one month and then thawed overnight at $+4{ }^{\circ} \mathrm{C}$ for the lipid oxidation analyses. The extent of lipid oxidation in the ground meat samples was assessed on the basis of the amount of malonaldehyde in the examined samples according to a spectrophotometric method (Tarladgis et al., 1960). Ten $\mathrm{g}$ of sample were homogenized in a Waring Blendor with $50 \mathrm{~mL}$ of distilled water for $2 \mathrm{~min}$. The mixture was then transferred into a Kjeldahl flask by washing with an additional $47.5 \mathrm{~mL}$ of distilled water and $2.5 \mathrm{~mL}$ of $\mathrm{HCI}$ solution was added to bring the $\mathrm{pH}$ to 1.5 . A few saddle stores were added to prevent bumping. Assemble apparatus and heat flasks were maintained at the highest heat on the Kjeldahl distillation apparatus. After distillation of $c a .10 \mathrm{~min}$ from the moment boiling began, $50 \mathrm{~mL}$ of distillate were collected and $5 \mathrm{~mL}$ portions of the distillate were immediately pipetted into equal amounts of TBA reagent in $50 \mathrm{~mL}$ glass stoppered tubes. After stoppering the tubes, the content was mixed and immersed in a boiling water bath for $35 \mathrm{~min}$. A distilled water-TBA reagent blank was prepared and treated like the samples. After heating, the tubes were cooled in tap water for $10 \mathrm{~min}$. The optical densities of the samples were read against 
a blank at a wavelength of $530 \mathrm{~nm}$. The absorbance was converted to $\mathrm{mg}$ of malonaldehyde per $1000 \mathrm{~g}$ of meat by multiplying by the factor of 7.8 (Tarladgis et al., 1960).

The data obtained from the experiment were analyzed statistically using the General Linear Model Procedure of SPSSWIN (1994). Significant differences between treatment means were separated using the Duncan's Multiple Range Test with a 5\% probability (Duncan, 1955).

Table 1 The ingredients and the calculated nutrient composition of the basal diets (as fed basis)

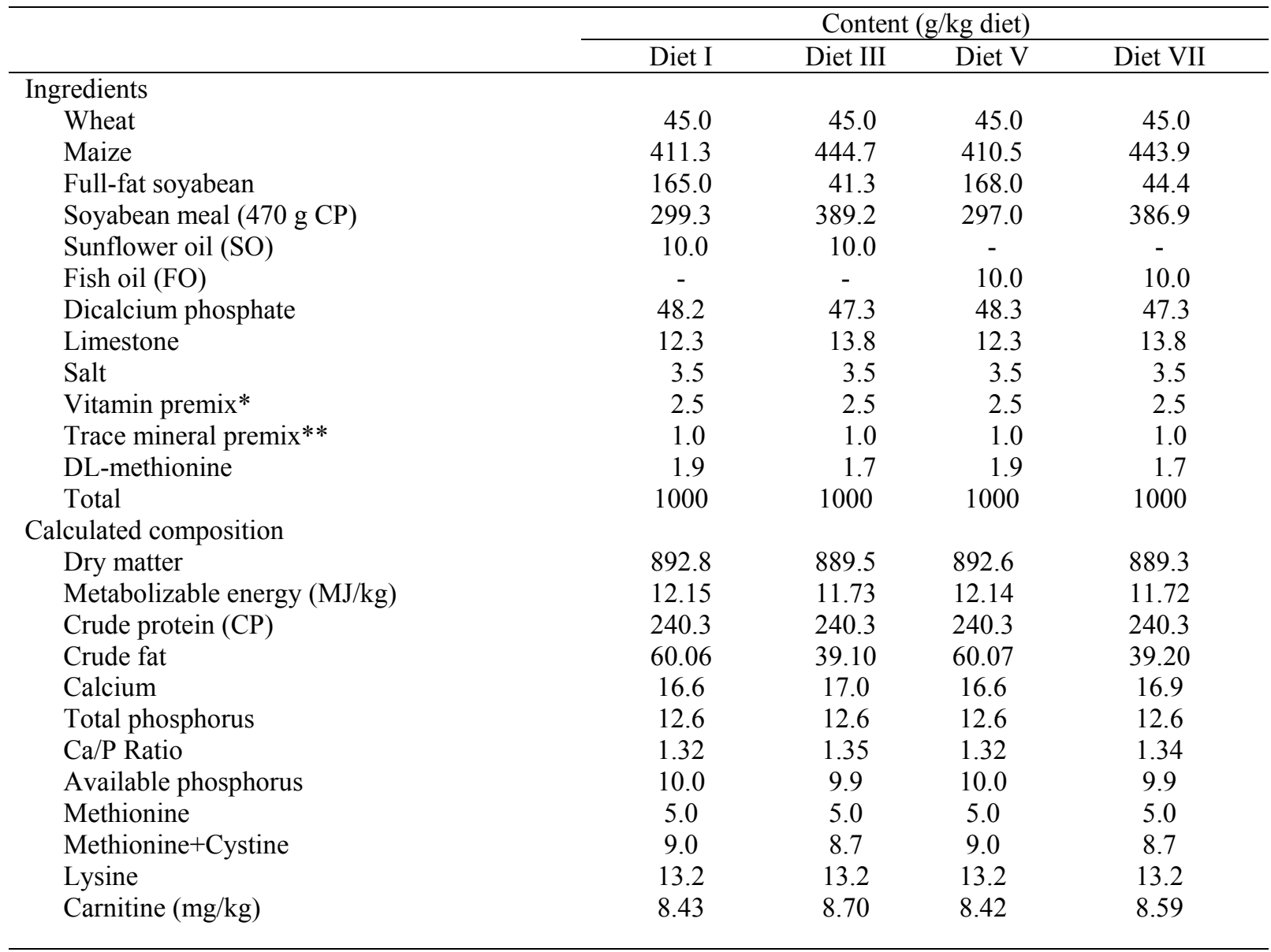

\footnotetext{
*Vitamin premix/kg diet: $12000 \mathrm{IU}$ Vitamin A; $1500 \mathrm{IU}$ vitamin $\mathrm{D}_{3} ; 50 \mathrm{mg}$ vitamin E; $5 \mathrm{mg}$ vitamin $\mathrm{K}_{3} ; 3 \mathrm{mg}$ vitamin $\mathrm{B}_{1} ; 6 \mathrm{mg}$ vitamin $\mathrm{B}_{2} ; 5 \mathrm{mg}$ vitamin $\mathrm{B}_{6} ; 0.03 \mathrm{mg}$ vitamin $\mathrm{B}_{12} ; 25 \mathrm{mg}$ niacin; $12 \mathrm{mg}$ Ca-D-pantothenate; $1 \mathrm{mg}$ folic acid; $0.05 \mathrm{mg}$ D-biotin; $2.5 \mathrm{mg}$ apo-carotenoic acid ester; $400 \mathrm{mg}$ choline chloride

**Trace mineral premix/kg diet: $80 \mathrm{mg} \mathrm{Mn;} 60 \mathrm{mg} \mathrm{Fe} ; 60 \mathrm{mg} \mathrm{Zn;} 5 \mathrm{mg} \mathrm{Cu} ; 0.2 \mathrm{mg} \mathrm{Co} ; 1 \mathrm{mg} \mathrm{I} ; 0.15 \mathrm{mg} \mathrm{Se}$
}

\section{Results and Discussion}

The effects of feeding diets containing two levels of ME and two fat sources with or without supplemental L-carnitine on body weight, body weight gain, feed intake and feed conversion ratio of quails are summarized in Table 2. Dietary treatments did not affect body weights gain, cumulative feed intakes and feed conversion ratio of the quails over the $28 \mathrm{~d}$ of the experimental period $(\mathrm{P}>0.05)$ (Table 2). However, at $5 \mathrm{wks}$ of age the body weights of the quails receiving the diets at the standard energy level (12.13 MJ $\mathrm{ME} / \mathrm{kg}$ ) were higher $(\mathrm{P}<0.05)$ than that of quails on the lower energy diets, irrespective of dietary fat source, level of added dietary L-carnitine and no interaction among dietary treatments were measured. These results are in agreement with others reported for Japanese quails (Sarica et al., 2005) and broiler chickens (Cartwright, 1986; Barker \& Sell, 1994; Rabie et al., 1997a; b; Celik et al., 2003). Sarica et al. (2005) reported that level of supplementary dietary L-carnitine did not affect body weight of Japanese quail chicks between 0 and $35 \mathrm{~d}$ of age. Similarly, Cartwright (1986) observed that body weight gain of broilers from 5 to 
7 wks of age was not affected by supplementing the diet with $500 \mathrm{mg} \mathrm{L}$-carnitine $/ \mathrm{kg}$. He also reported that six and seven week body weights were significantly heavier in broilers fed high energy compared to low energy diets. Barker \& Sell (1994) reported that the supplementation of dietary L-carnitine at 0,50 or 100 $\mathrm{mg} / \mathrm{kg}$ diet did not influence the body weight of broiler chickens fed low- or high-fat diets. Rabie et al. (1997a; b) showed that L-carnitine supplementation to diets had no significant effect on body weight of broilers at the end of the experimental period. Likewise, Celik et al. (2003) pointed out that no significant differences were detected in the body weights of broilers fed diets supplemented with L-carnitine.

Table 2 The effects of feeding diets containing different levels of metabolizable energy (ME) and different fat sources with or without supplemental L-carnitine on body weight, body weight gain, cumulative feed intake and the feed conversion ratio of quails

\begin{tabular}{|c|c|c|c|c|c|c|c|c|c|c|}
\hline & \multirow{2}{*}{$\begin{array}{l}\text { Energy } \\
\text { level }\end{array}$} & \multirow{2}{*}{$\begin{array}{c}\text { L- } \\
\text { carnitine } \\
\text { level }\end{array}$} & \multicolumn{2}{|c|}{$\begin{array}{l}\text { Body weight } \\
\text { g }\end{array}$} & \multicolumn{2}{|c|}{$\begin{array}{c}\text { Body weight gain } \\
\mathrm{g}\end{array}$} & \multicolumn{2}{|c|}{$\begin{array}{l}\text { Cumulative feed } \\
\text { intake, } g\end{array}$} & \multicolumn{2}{|c|}{$\begin{array}{l}\text { Feed conversion ratio } \\
\mathrm{g} / \mathrm{g}\end{array}$} \\
\hline & & & $0 \mathrm{~d}$ & $35 \mathrm{~d}$ & 0 to $28 \mathrm{~d}$ & 0 to $35 \mathrm{~d}$ & 0 to $28 \mathrm{~d}$ & 0 to $35 \mathrm{~d}$ & 0 to $28 \mathrm{~d}$ & 0 to $35 \mathrm{~d}$ \\
\hline \multicolumn{11}{|c|}{ Fat source* } \\
\hline SO & 12.13 & 0 & 7.6 & 168.3 & 132.6 & 160.7 & 370.2 & 539.3 & 2.8 & 3.4 \\
\hline SO & 12.13 & 50 & 7.5 & 167.5 & 129.2 & 160.0 & 372.2 & 551.7 & 2.9 & 3.5 \\
\hline SO & 11.72 & 0 & 7.5 & 162.1 & 129.0 & 154.6 & 379.0 & 556.3 & 2.9 & 3.6 \\
\hline SO & 11.72 & 50 & 7.6 & 164.5 & 129.5 & 156.9 & 377.8 & 556.3 & 2.9 & 3.6 \\
\hline FO & 12.13 & 0 & 7.7 & 170.4 & 130.6 & 162.7 & 371.0 & 555.2 & 2.8 & 3.4 \\
\hline FO & 12.13 & 50 & 7.6 & 165.8 & 127.2 & 158.2 & 366.8 & 552.2 & 2.9 & 3.5 \\
\hline FO & 11.72 & 0 & 7.6 & 163.5 & 126.5 & 155.9 & 376.2 & 559.3 & 3.0 & 3.6 \\
\hline $\mathrm{FO}$ & 11.72 & 50 & 7.7 & 163.3 & 128.2 & 155.6 & 373.7 & 550.8 & 2.9 & 3.5 \\
\hline \multicolumn{11}{|c|}{ Effect of fat sources* } \\
\hline SC & & & 7.6 & 165.6 & 130.1 & 158.0 & 374.8 & 550.9 & 2.9 & 3.5 \\
\hline $\mathrm{FC}$ & & & 7.7 & 165.8 & 128.1 & 158.1 & 371.9 & 554.4 & 2.9 & 3.5 \\
\hline \multicolumn{11}{|c|}{ Effect of energy level (MJ ME/kg) } \\
\hline 12 & & & 7.6 & $168.0^{\mathrm{a}}$ & 129.9 & $160.4^{\mathrm{a}}$ & 370.0 & 549.6 & 2.9 & $3.5^{\mathrm{b}}$ \\
\hline 11 & & & 7.6 & $163.4^{\mathrm{b}}$ & 128.3 & $155.8^{\mathrm{b}}$ & 376.7 & 555.7 & 2.9 & $3.6^{\mathrm{a}}$ \\
\hline \multicolumn{11}{|c|}{ Effect of L-carnitine level $(\mathrm{mg} / \mathrm{kg})$} \\
\hline 0 & & & 7.6 & 166.1 & 129.7 & 158.5 & 374.1 & 552.5 & 2.9 & 3.5 \\
\hline 50 & & & 7.6 & 165.3 & 128.5 & 157.7 & 372.6 & 552.8 & 2.9 & 3.5 \\
\hline & d s.e.m. & & 0.102 & 0.994 & 0.844 & 0.955 & 2.289 & 3.3863 & 0.0184 & 0.023 \\
\hline \multicolumn{11}{|c|}{ Source of variation (P value) } \\
\hline $\mathrm{Fa}$ & & & 0.701 & 0.948 & 0.288 & 0.984 & 0.583 & 0.655 & 0.533 & 0.592 \\
\hline & & & 0.943 & 0.034 & 0.380 & 0.025 & 0.215 & 0.432 & 0.023 & 0.002 \\
\hline & iitine & & 0.906 & 0.700 & 0.548 & 0.672 & 0.780 & 0.978 & 0.730 & 0.654 \\
\hline & Energy & & 0.952 & 0.985 & 0.980 & 0.990 & 0.905 & 0.544 & 0.935 & 0.452 \\
\hline & L-carnitin & & 0.963 & 0.436 & 0.865 & 0.413 & 0.720 & 0.445 & 0.558 & 0.953 \\
\hline & y x L-carr & tine & 0.672 & 0.354 & 0.231 & 0.354 & 0.943 & 0.566 & 0.155 & 0.099 \\
\hline & Energy $\mathrm{x}$ & -carnitine & 0.965 & 0.884 & 0.881 & 0.881 & 0.817 & 0.825 & 0.948 & 0.879 \\
\hline
\end{tabular}

* SO - sunflower oil; FO - fish oil

${ }^{\mathrm{a}, \mathrm{b}}$ Means in the same column with like superscripts letters were not significantly different $(\mathrm{P}>0.05)$

Pooled s.e.m. - Pooled standard error of the differences among (or between) means

As indicated in Table 2, feeding the diet containing the standard energy level (12.13 MJ ME/kg) increased body weight gain and improved feed conversion ratio $(\mathrm{P}<0.05)$ of the quails above those on the lower energy diet. Similarly, Rabie \& Szilagyi (1998) reported significant reductions in body weight gain and deterioration in feed conversion of broilers over the experimental period when dietary energy level was decreased from 13.5 to $12.2 \mathrm{MJ} \mathrm{ME} / \mathrm{kg}$ diet. In the present study feed intake of the quails was not affected $(\mathrm{P}>0.05)$ by any of the dietary treatments (Table 2), in agreement with other research (Barker \& Sell, 1994; Leibetseder, 1995; Rabie \& Szilagyi, 1998; Lien \& Horng, 2001; Xu et al., 2003). Barker \& Sell (1994) observed no effect of supplemental dietary L-carnitine at levels of 0,50 or $100 \mathrm{mg} / \mathrm{kg}$ diet, on body weight 
gain, feed intake and feed efficiency of broiler chickens fed on low- or high-fat diets. Similarly, Leibetseder (1995) recorded that body weight gain and feed conversion ratio of broiler chickens were not influenced by dietary carnitine (L or DL form) at $200 \mathrm{mg} / \mathrm{kg}$.

Lien \& Horng (2001) recorded that the supplementation of $160 \mathrm{mg}$ of L-carnitine $/ \mathrm{kg}$ did not significantly influence the growth performance of broiler chickens. Xu et al. (2003) found no significant differences in body weight gain, feed intake or feed conversion of male broilers fed a diet supplemented with $0,25,50,75$ or $100 \mathrm{mg}$ L-carnitine/kg diet. Contrary to these findings, Rabie et al. (1997b) reported that dietary L-carnitine supplementation at three levels $(50,100$ or $150 \mathrm{mg} / \mathrm{kg}$ ) significantly increased body weight gain of broiler chickens compared with those on a basal diet. These inconsistencies between studies could be the result of differences in levels of L-carnitine supplementation, levels of methionine and lysine in the diets, differences in ingredients and ME levels, the sexes of birds and/or the physiological status of the birds. No mortalities were recorded during the present experiment.

Carcass yields and carcass components of the quails at $35 \mathrm{~d}$ of age are presented in Table 3. Only limited information could be found in the literature on the effect of dietary L-carnitine supplementation on carcass yield or carcass components of poultry and other species. All carcass parameters studied except cold carcass yield and thigh yield were unaffected by fat source, dietary energy level or L-carnitine supplementation. Similarly, the interactions between dietary treatments were not significant for all carcass variables recorded except for cold carcass yield and thigh yield. The cold carcass yield of quails fed on the diets containing sunflower oil was higher than that of the birds on the diets containing fish oil $(\mathrm{P}<0.05)$. At $35 \mathrm{~d}$ of age the feeding the diets at standard energy level $(12.13 \mathrm{MJ} \mathrm{ME} / \mathrm{kg})$ resulted in significant higher thigh yields (thighs plus drumsticks with bones) compared with the quails receiving the low energy diets.

The results of the present study are consistent with those of others (Cartwright, 1986; Barker \& Sell, 1994; Rabie et al., 1997a; b; Leibetseder, 1995; Lien \& Horng, 2001; Kita et al., 2002; Arslan et al., 2004). Cartwright (1986) found no significant effect on abdominal fat when L-carnitine was fed at.500 $\mathrm{mg} / \mathrm{kg}$ diet from 5 to 7 wk of age. Barker \& Sell (1994) reported that supplemental dietary L-carnitine (50 or 100 $\mathrm{mg} / \mathrm{kg}$ ) did not affect abdominal fat weight and breast meat yield of broiler chickens fed low- or high-fat diets. Leibetseder (1995) investigated the effect of carnitine and its precursors (methionine and lysine) in reducing the formation of abdominal fat in broiler chickens fed diets supplemented with 0 or $50 \mathrm{~g}$ fat $/ \mathrm{kg}$. He pointed out that abdominal fat content of broilers was not influenced by dietary carnitine supplementation (L or DL form) at a level of $200 \mathrm{mg} / \mathrm{kg}$ diet. Rabie et al. (1997a; b) noted that L-carnitine supplementation to broiler diets did not affect body weight at slaughter, absolute weights of eviscerated carcass, liver, heart, gizzard and giblets, breast and thigh yield and weight of total edible parts except abdominal fat pad weights. Lien \& Horng (2001) demonstrated that supplementary carnitine did not significantly influence the abdominal fat pad and liver weight of broilers. Kita et al. (2002) also found that L-carnitine supplementation did not affect liver weights. Rabie \& Szilagyi (1998) reported that dietary energy level, L-carnitine supplementation or the interaction between them did not affect heart, gizzard and giblets weights significantly. However, they found significant increases in breast and thigh meat yields and significant reductions in abdominal fat contents of broilers when supplementing L-carnitine. They also pointed out that a reduction in the dietary energy level from 13.5 to $12.2 \mathrm{MJ} \mathrm{ME} / \mathrm{kg}$ in grower-finisher diets of broilers resulted in significant reductions in the $53 \mathrm{~d}$ body weight and concomitant decreases in weights of eviscerated carcass, liver, breast and breast meat yields, thigh and thigh meat yields, total edible parts and abdominal fat content of 53-d old broiler chickens. Lettner et al. (1992), Xu et al. (2002) and Xu et al. (2003) found that the abdominal fat content was significantly decreased by dietary L-carnitine supplementation. Although the carnitine groups in the present study consumed more L-carnitine than the control group, it had no positive effect on carcass yield and components and abdominal fat content of the 35-d old quails. The level of dietary L-carnitine used, the fat sources, ME levels of diets as well as the physiological status, sex and age of the quails might have contributed to the present results. 
Table 3 Mean values (g) for carcass yields and components of 35-d old quails fed the diets containing two levels metabolizable energy (ME) and two different sources of fat with or without supplemental L-carnitine from 0 to $35 \mathrm{~d}$ of age

\begin{tabular}{|c|c|c|c|c|c|c|c|c|c|c|c|c|c|c|c|c|}
\hline & $\begin{array}{l}\text { Energy } \\
\text { level }\end{array}$ & $\begin{array}{c}\text { L-carnitine } \\
\text { level }\end{array}$ & BW & $\begin{array}{c}\text { Hot } \\
\text { carcass }\end{array}$ & $\mathrm{EC}$ & $\mathrm{HCY}$ & $\mathrm{CCY}$ & Liver & Heart & Gizzard & BY & $\mathrm{BM}$ & TY & $\mathrm{TM}$ & TEP & $\mathrm{AF}$ \\
\hline \multicolumn{17}{|c|}{ Fat source* } \\
\hline SO & 12.13 & 0 & 172.4 & 112.2 & 111.9 & 65.3 & 65.1 & 4.2 & 1.7 & 4.1 & 37.5 & 33.5 & 34.1 & 30.5 & 121.9 & 2.5 \\
\hline SO & 12.13 & 50 & 176.0 & 113.5 & 113.2 & 64.6 & 64.4 & 4.1 & 1.6 & 4.0 & 38.8 & 34.8 & 34.7 & 31.4 & 122.8 & 1.7 \\
\hline SO & 11.72 & 0 & 163.0 & 103.5 & 103.0 & 63.7 & 63.4 & 4.3 & 1.5 & 4.0 & 39.3 & 35.7 & 35.3 & 31.5 & 112.9 & 1.8 \\
\hline SO & 11.72 & 50 & 177.0 & 112.5 & 112.2 & 63.7 & 63.5 & 3.5 & 1.6 & 3.8 & 37.6 & 33.8 & 32.0 & 28.8 & 121.0 & 1.8 \\
\hline FO & 12.13 & 0 & 172.7 & 109.4 & 108.7 & 63.6 & 63.2 & 3.8 & 1.6 & 4.2 & 39.6 & 36.1 & 35.5 & 30.3 & 118.3 & 1.6 \\
\hline FO & 12.13 & 50 & 171.9 & 108.0 & 107.6 & 62.6 & 62.6 & 4.1 & 1.5 & 4.0 & 39.5 & 35.9 & 35.3 & 31.6 & 117.2 & 1.5 \\
\hline FO & 11.72 & 0 & 164.9 & 103.2 & 101.5 & 62.6 & 61.5 & 3.8 & 1.6 & 3.9 & 38.1 & 34.7 & 33.0 & 29.7 & 110.7 & 1.7 \\
\hline FO & 11.72 & 50 & 168.8 & 107.6 & 107.2 & 63.9 & 63.7 & 3.4 & 1.6 & 4.0 & 39.2 & 34.8 & 32.9 & 29.8 & 116.3 & 1.4 \\
\hline \multicolumn{17}{|c|}{ Effect of fat sources* } \\
\hline SO & & & 172.1 & 110.4 & 110.1 & 64.3 & $64.1^{\mathrm{a}}$ & 4.0 & 1.6 & 4.0 & 38.3 & 34.5 & 34.0 & 30.6 & 119.7 & 2.0 \\
\hline FO & & & 169.6 & 107.0 & 106.3 & 63.2 & $62.8^{\mathrm{b}}$ & 3.8 & 1.6 & 4.0 & 39.1 & 35.4 & 34.2 & 30.3 & 115.6 & 1.6 \\
\hline \multicolumn{17}{|c|}{ Effect of energy level (MJ ME/kg) } \\
\hline 12.13 & & & 173.3 & 110.8 & 110.4 & 64.0 & 63.8 & 4.0 & 1.6 & 4.1 & 38.9 & 35.1 & $34.9^{\mathrm{a}}$ & 31.0 & 120.0 & 1.8 \\
\hline 11.72 & & & 168.4 & 106.7 & 106.0 & 63.5 & 63.0 & 3.8 & 1.6 & 3.9 & 38.6 & 34.8 & $33.3^{\mathrm{b}}$ & 30.0 & 115.2 & 1.7 \\
\hline \multicolumn{17}{|c|}{ Effect of L-carnitine level (mg/kg) } \\
\hline 0 & & & 168.3 & 107.1 & 106.3 & 63.8 & 63.3 & 4.0 & 1.6 & 4.0 & 38.6 & 35.0 & 34.5 & 30.5 & 116.0 & 1.9 \\
\hline 50 & & & 173.4 & 110.4 & 110.0 & 63.7 & 63.6 & 3.8 & 1.6 & 4.0 & 38.8 & 34.8 & 33.7 & 30.4 & 119.3 & 1.6 \\
\hline Pooled s & & & 2.117 & 1.276 & 1.288 & 0.295 & 0.315 & 0.136 & 0.026 & 0.075 & 0.468 & 0.459 & 0.360 & 0.320 & 1.430 & 0.122 \\
\hline \multicolumn{17}{|c|}{ Source of variation (P value) } \\
\hline Fat & & & 0.556 & 0.184 & 0.136 & 0.072 & 0.035 & 0.351 & 0.972 & 0.737 & 0.407 & 0.324 & 0.888 & 0.743 & 0.229 & 0.096 \\
\hline Energ & & & 0.265 & 0.114 & 0.089 & 0.301 & 0.193 & 0.240 & 0.673 & 0.397 & 0.780 & 0.767 & 0.026 & 0.137 & 0.139 & 0.476 \\
\hline L-can & & & 0.230 & 0.195 & 0.143 & 0.957 & 0.708 & 0.350 & 0.430 & 0.613 & 0.880 & 0.862 & 0.299 & 0.896 & 0.329 & 0.248 \\
\hline Fat $\mathrm{x}$ & & & 0.879 & 0.767 & 0.816 & 0.281 & 0.384 & 0.907 & 0.268 & 0.934 & 0.522 & 0.324 & 0.241 & 0.759 & 0.987 & 0.605 \\
\hline Fat $x$ & tine & & 0.402 & 0.474 & 0.569 & 0.583 & 0.394 & 0.379 & 0.968 & 0.576 & 0.727 & 0.902 & 0.426 & 0.232 & 0.843 & 0.682 \\
\hline Energ & arnitine & & 0.385 & 0.191 & 0.151 & 0.251 & 0.150 & 0.226 & 0.291 & 0.804 & 0.640 & 0.445 & 0.190 & 0.069 & 0.166 & 0.423 \\
\hline Fat $\mathrm{x}$ & x L-carni & & 0.738 & 0.841 & 0.927 & 0.563 & 0.417 & 0.962 & 0.881 & 0.476 & 0.302 & 0.354 & 0.164 & 0.371 & 0.807 & 0.278 \\
\hline
\end{tabular}

BW - body weight at slaughter; EC - eviscerated carcass (cooled carcass weight without neck and abdominal fat); HCY - hot carcass yield; CCY - cold carcass yield;

BY - breast yield; BM - breast meat; TY - thigh plus drumstick yield; TM - thigh plus drumstick meat; AF - abdominal fat; TEP - total edible meat (EC plus giblets; the

latter includes the edible offal of the carcass, i.e. liver, heart and gizzard)

* SO - sunflower oil; FO - fish oil

${ }^{\mathrm{a}, \mathrm{b}}$ Means in the same column with like superscripts letters were not significantly different $(\mathrm{P}>0.05)$

Pooled s.e.m. - Pooled standard error of the differences among (or between) means 
In theory dietary L-carnitine supplementation could play a role in reducing undesirable carcass fat in poultry. It is suggested that if dietary fat sources rich in long-chain fatty acids have been included in the diets at levels higher than $10 \mathrm{~g} / \mathrm{kg}$, and if different levels of L-carnitine were investigated, the role of dietary L-carnitine supplementation in energy metabolism might have been more evident, especially its effects on carcass parameters, abdominal fat content and ether extract contents of total edible meat of quails. The abdominal fat and ether extract contents of total edible meat of the quails might have been influenced by differences in the fatty acid composition of dietary fat because L-carnitine has a key role in facilitating the transport of long-chain fatty acids across the inner mitochondrial membrane for $\beta$-oxidation to generate ATP, thereby reducing their availability for esterification to triacylglycerols and storage in the adipose tissues (Rabie \& Szilagyi, 1998).

As shown in Table 4, dietary treatments did not affect the $\mathrm{pH}$ of total edible meat in quails at any stage of the study $(\mathrm{P}>0.05)$. No information could be obtain from the literature on the effect of dietary $\mathrm{L}$-carnitine, ME levels and fat source on $\mathrm{pH}$ values of total edible quail meat.

Table 4 The effects of feeding with the diets containing two metabolizable energy (ME) levels and two fat sources with or without supplemental L-carnitine on $\mathrm{pH}$ and MA amounts of total edible meat in quails

\begin{tabular}{|c|c|c|c|c|}
\hline & Energy level & $\begin{array}{c}\text { L-carnitine } \\
\text { level }\end{array}$ & $\mathrm{pH}$ & $\begin{array}{l}\text { MA (mg/kg } \\
\text { sample)** }\end{array}$ \\
\hline \multicolumn{5}{|l|}{ Fat Source* } \\
\hline SO & 12.13 & 0 & 6.2 & 3.8 \\
\hline SO & 12.13 & 50 & 6.2 & 2.4 \\
\hline SO & 11.72 & 0 & 6.2 & 4.2 \\
\hline SO & 11.72 & 50 & 6.2 & 2.0 \\
\hline $\mathrm{FO}$ & 12.13 & 0 & 6.3 & 5.8 \\
\hline FO & 12.13 & 50 & 6.2 & 3.5 \\
\hline $\mathrm{FO}$ & 11.72 & 0 & 6.2 & 5.3 \\
\hline $\mathrm{FO}$ & 11.72 & 50 & 6.3 & 2.8 \\
\hline \multicolumn{5}{|l|}{ Effect of fat sources* } \\
\hline SO & & & 6.2 & $3.1^{\mathrm{b}}$ \\
\hline FO & & & 6.3 & $4.4^{\mathrm{a}}$ \\
\hline \multicolumn{5}{|l|}{ Effect of energy level (MJ ME $/ \mathrm{kg}$ ) } \\
\hline 12.13 & & & 6.2 & 3.9 \\
\hline 11.72 & & & 6.2 & 3.6 \\
\hline \multicolumn{5}{|l|}{ Effect of L-carnitine level (mg/kg) } \\
\hline 0 & & & 6.2 & $4.8^{\mathrm{a}}$ \\
\hline 50 & & & 6.2 & $2.7^{\mathrm{b}}$ \\
\hline Pooled s.e.m. & & & 0.082 & 0.202 \\
\hline \multicolumn{5}{|l|}{ Source of variation (P value) } \\
\hline Fat & & & 0.066 & 0.001 \\
\hline Energy & & & 0.483 & 0.337 \\
\hline L-carnitine & & & 0.689 & 0.001 \\
\hline Fat $x$ Energy & & & 0.423 & 0.352 \\
\hline Fat x L-carnitine & & & 0.368 & 0.362 \\
\hline Energy x L-carnitine & & & 0.582 & 0.299 \\
\hline Fat x Energy x L-carnitine & & & 0.802 & 0.566 \\
\hline
\end{tabular}

* SO - sunflower oil; FO - fish oil

** MA - malonaldehyde

${ }^{a, b}$ Means in the same column with like superscripts letters were not significantly different $(\mathrm{P}>0.05)$

Pooled s.e.m. - Pooled standard error of the differences among (or between) means

Quails fed diets containing sunflower oil had lower malonaldehyde (MA) amounts than the ones receiving the diets containing fish oil $(\mathrm{P}<0.05)$. Such a response is related to the higher level of long-chain 
fatty acids in fish oil compared to sunflower oil. However, there was no reduction $(\mathrm{P}>0.05)$ in MA amounts of total edible meat in quails when the dietary energy level was decreased from 12.13 to $11.72 \mathrm{MJ} \mathrm{ME} / \mathrm{kg}$ diet. Level of dietary energy did not have any significant effect on the ether extract content of the meat. Therefore, a significant effect of dietary energy level on MA amounts was not expected. However, dietary L-carnitine supplementation decreased $(\mathrm{P}<0.05) \mathrm{MA}$ amounts of meat compared to the control. Decreasing MA amounts of edible meat observed in the present study in response to L-carnitine supplementation might be attributed at least partly to an increased rate of the transport of long-chain fatty acids into the mitochondria. Dietary L-carnitine supplementation promotes the $\beta$-oxidation of these fatty acids to generate ATP energy and improves energy utilisation (Rabie et al., 1997b; Neuman et al., 2002). Consequently, L-carnitine supplementation to diets reduces the amount of long-chain fatty acids availability for esterification to triacylglycerols and storage in the adipose tissue (Barker \& Sell, 1994; Xu et al., 2003).

Table 5 The effects of feeding with the diets containing two metabolizable energy (ME) levels and two fat sources with or without supplemental L-carnitine on nutrient composition of total edible meat in quails

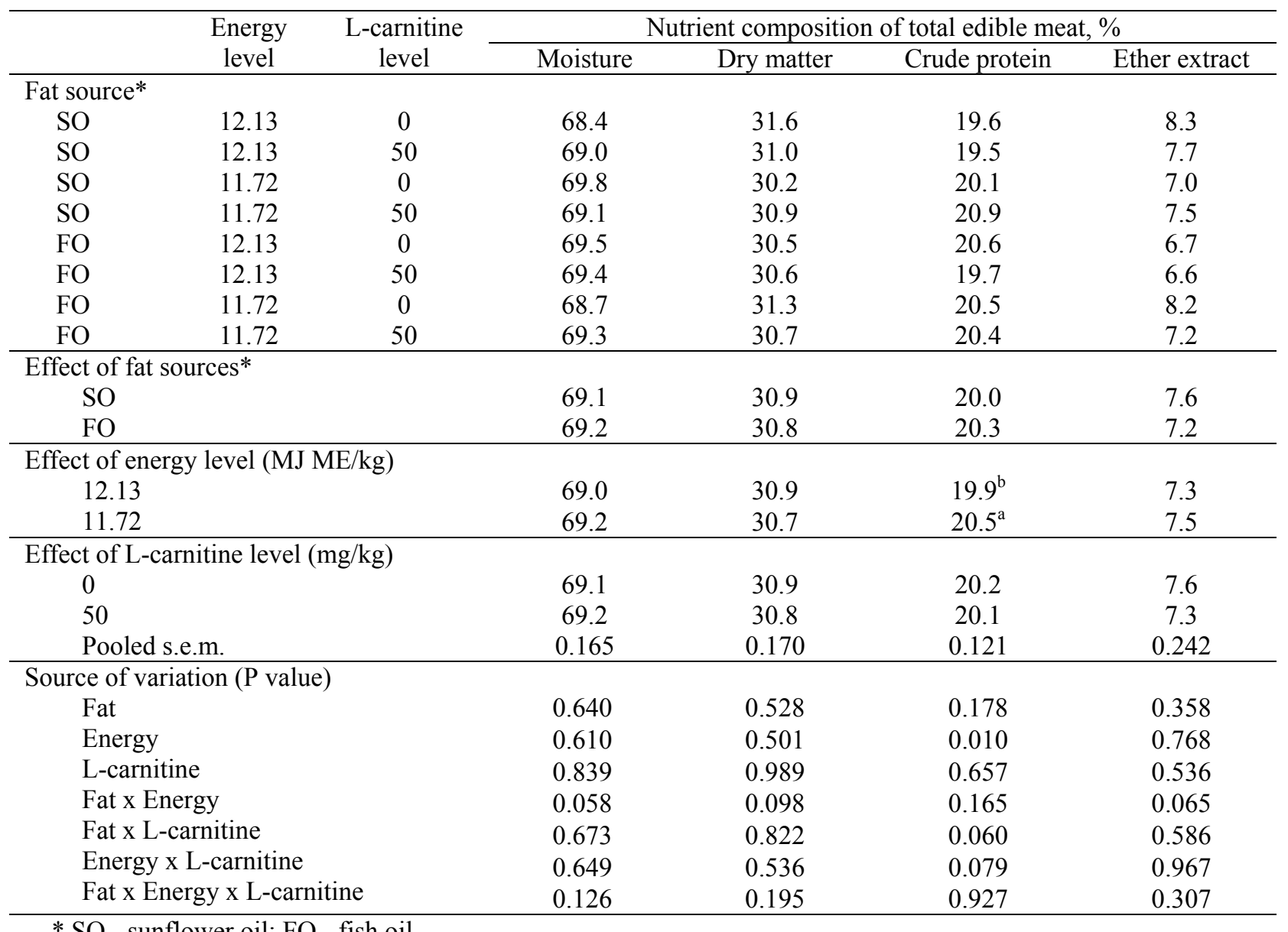

* SO - sunflower oil; FO - fish oil

a,b Means in the same column with like superscripts letters were not significantly different $(\mathrm{P}>0.05)$

Pooled s.e.m. - Pooled standard error of the differences among (or between) means

Dietary treatments did not affect the DM, moisture, CP and ether extract content of the edible meat (breast plus thigh meat) of the quails at 35-d of age (Table 5). The CP content of the edible meat increased $(\mathrm{P}<0.05)$ when dietary energy level decreased from 12.13 to $11.72 \mathrm{MJ} \mathrm{ME} / \mathrm{kg}$ diet. These findings concur with that of other authors (Barker \& Sell, 1994; Rabie et al., 1997b; Celik \& Ozturkcan, 2003). Barker \& Sell (1994) noted that percentage carcass DM or moisture, CP and ether extract were not influenced by dietary L-carnitine supplementation, irrespective of the level of dietary fat. They pointed out that percentage 
carcass protein significantly decreased as dietary ME increased with the increase in dietary fat supplementation from 10 to $50 \mathrm{~g} / \mathrm{kg}$. Rabie et al. (1997b) reported that L-carnitine supplementation to broiler diets did not significantly affect the DM, CP and ether extract content of breast and thigh meat. Celik \& Ozturkcan (2003) showed that carcass DM, crude fat and CP content in broiler chickens were not significantly influenced by dietary L-carnitine supplementation. However, Xu et al. (2003) reported that the crude fat content in breast muscle of male broilers increased significantly upon the supplementation of 50 and $75 \mathrm{mg}$ L-carnitine/kg diet.

Table 6 The effects of dietary treatments on "L", "a" and "b" values of quail meat

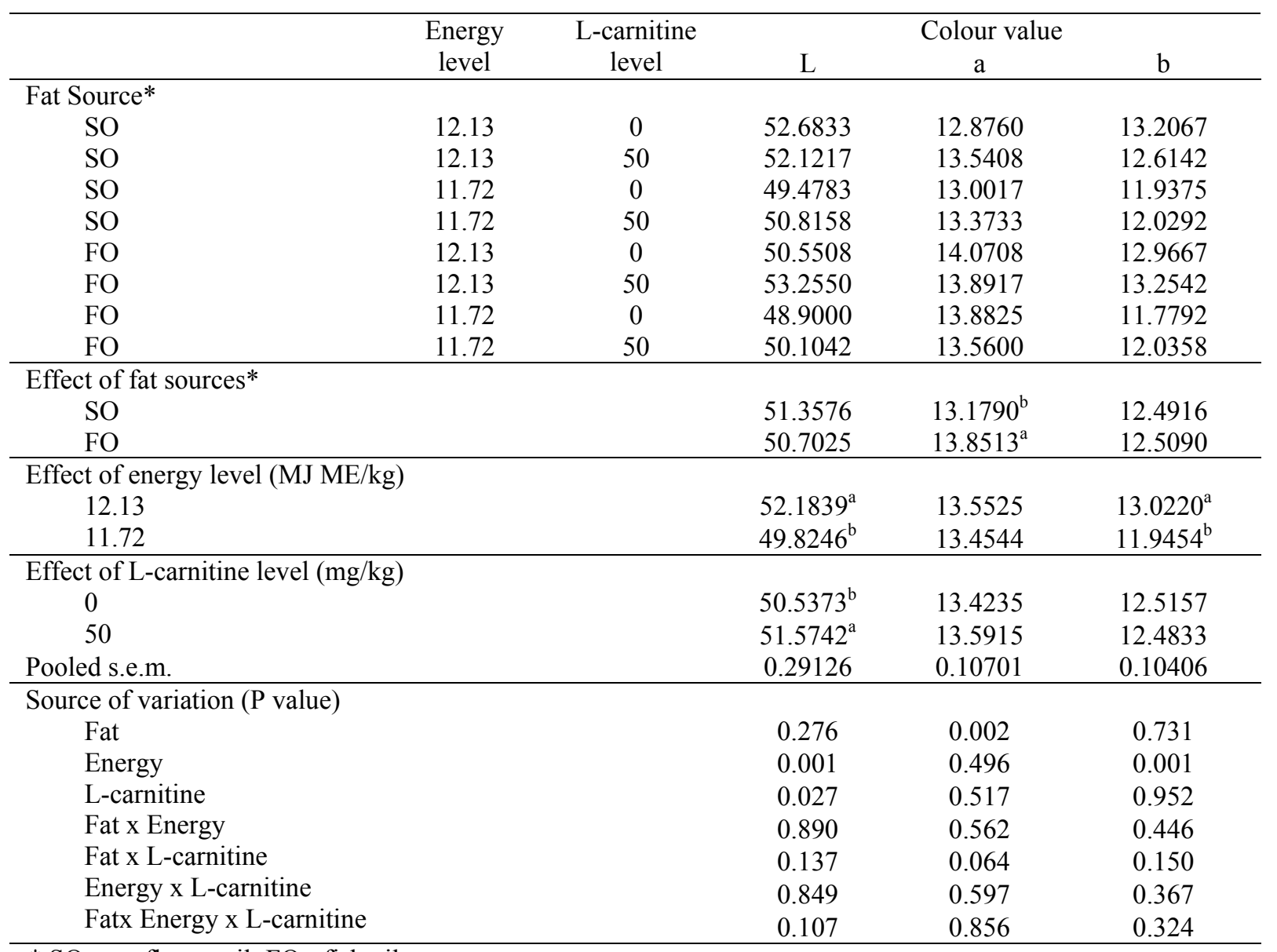

* SO - sunflower oil; FO - fish oil

${ }^{a, b}$ Means in the same column with like superscripts letters were not significantly different $(P>0.05)$

Pooled s.e.m. - Pooled standard error of the differences among (or between) means

L - Lightness; a - Redness; b - Yellowness

The effects of dietary treatments on "L", "a" and "b" values of quail meat are presented in Table 6. An increase in dietary energy level from 11.72 to $12.13 \mathrm{MJ} \mathrm{ME} / \mathrm{kg}$ diet increased $(\mathrm{P}<0.05)$ the lightness and yellowness of the meat. The presence of xanthophyll in maize might have increased the yellow colour in the meat. Likewise, dietary L-carnitine supplementation resulted in a significant increase in "L" value. Such a response could be related to the inhibiting effect of L-carnitine supplementation on muscle myoglobin oxidation in the meat. The meat of the quails receiving the diets containing fish oil was significantly more red (higher "a" value) than those of quails fed the diets containing sunflower oil. Other dietary treatments except the fat source did not affect the "a" value of meat. Fish oil contains astaxanthin, a naturally occurring carotenoid red pigment. This is a powerful biological antioxidant protecting cell membranes, cells and tissues against lipid peroxidation. The present result could be attributed to the astaxanthin content of fish oil. 
There was a significant reduction in the "b" value (less yellow) of quail meat when the dietary energy level was decreased from 12.13 to $11.72 \mathrm{MJ} \mathrm{ME} / \mathrm{kg}$ diet.

\section{Conclusions}

The feeding of diets with a standard energy level (12.13 MJ ME/kg) significantly increased body weight, body weight gain and improved feed conversion ratio and inhibited myoglobin oxidation by increasing the yellow colour of meat in Japanese quails compared to the low energy diets. The diets lower in energy level significantly increased the CP content of total edible meat of the quails. Use of fish oil with supplemental L-carnitine in quail diets or feeding diets containing sunflower oil significantly increased the shelflife stability of meat.

Further investigations are required to identify the role of L-carnitine in the oxidation of long-chain fatty acids, its antioxidant properties and importance in energy metabolism. The effects of L-carnitine when feeding diets with higher levels of dietary fat on the fatty acid composition of quail meat, the activity of antioxidant enzymes in carcass parameters and serum, and changes in MA amounts, colour and $\mathrm{pH}$ values of meat under different storage conditions require further investigation.

\section{References}

Arslan, C., Citil, M. \& Saatci, M., 2004. Effects of L-carnitine administration on growth performance, carcass traits and some serum components of Japanese quail (Coturnix cot. japonica). Arch. Geflügelk. 68 (3), 111-114.

AOAC, 1984. Official Methods of Analysis (14 ${ }^{\text {th }}$ ed.). Ed. Williams, S., Association of Official Analytical Chemists, Inc., Arlinton, Virginia, USA.

Barker, D.L. \& Sell, J.L., 1994. Dietary carnitine did not influence performance and carcass composition of broiler chickens and young turkeys fed low- or high-fat diets. Poult. Sci. 73, 281-287.

Baumgartner, M. \& Blum, R., 1993. L-carnitine in animal nutrition. In: Vitamine and weitere zusatzstoffe bei mensch und tier (Vitamins and other supplements for humans and animals). Eds. Flachowsky, G. \& Schubert, R., Friedrich-Schiller Univ., Jena, Germany. pp. 413-418.

Bieber, L.L., 1988. Carnitine. Annu Rev Biochem. 57, 261-283.

Blanch, A., Barroeta, A.C., Baucells, M.D. \& Punchal, F., 1995. The nutritive value of dietary fats in relation to their chemical composition. Apparent fat availability and metabolizable energy in two-week-old chicks. Poult. Sci. 74, 1335-1340.

Borum, P.R., 1987. Role of carnitine in lipid metabolism. In: Lipids in Modern Nutrition. Eds. Horisberger, M. \& Bracco, U., Vevey/New York. pp. 51-58.

Bremer, J., 1983. Carnitine metabolism and functions. Physiol. Rev. 63, 1420-1480.

Cartwright, A.L., 1986. Effect of carnitine and dietary energy concentration on body weight and body lipid of growing broilers. Poult. Sci. 65 (Suppl 1), 21-29 (Abstr.).

Celik, L. \& Ozturkcan, O., 2003. Effects of dietary supplemental L-carnitine and ascorbic acid on performance, carcass composition and plasma L-carnitine concentration of broiler chicks reared under different temperature. Arch. Anim. Nutr. 57 (1), 27-38.

Celik, L., Ozturkcan, O., Inal, T.C., Canacankatan, N. \& Kayrin, L., 2003. Effects of L-carnitine and niacin supplied by drinking water on fattening performance, carcass quality and plasma L-carnitine concentration of broiler chicks. Arch. Anim. Nutr. 57, 127-136.

Cherian, G., Wolfe, F.W. \& Sim, J.S., 1996. Dietary oils with added tocopherols affects on egg or tissue tocopherols, fatty acids and oxidative stability. Poult. Sci. 75, 423-432.

Duncan, D.B., 1955. Multiple range test and multiple F tests. Biometrics 11, 1-42.

Ensoy, U., Candogan, K., Kolsarici, N., Karslioglu, B. \& Cizmeci, M., 2004. Influence of acetic acid and lactic acid treatments on lipid changes and color of chicken legs. XXII World's Poultry Congress. 2004 June 8-13; Istanbul/Turkey. 874 pp.

Gropp, J.M., Schumacher, A. \& Schweigert, F.J., 1994. Recent research in vitamin nutrition with special emphasis to vitamin A, $\beta$-carotene and L-carnitine. In: Proc., Meeting Arkansas Nutr. Conf., Fayetteville, A. R: Arkansas Poultry Federation. pp. 124-134.

Harmeyer, J., 2002. The physiological role of L-carnitine. Lohmann-Information. 27, 15-22. 
Harmeyer, J., Schlumbohm, C. \& Baumgartner, M., 1998. Carnitine content in feed and food of vegetable and animal origin and the impact of processing on the content. In: Einfluss von erzeugung und verarbeitung auf die qualitat landwirtschaftlicher produkte, Ed VDLUFA Verlag, Darmstad, Germany. pp. 489-492. (In German).

Janssens, G.P.J., Mast, J., Goddeeris, B.M., Cox, E., Hesta, M. \& De Wilde, R.O.M., 2000. Enhanced specific antibody response to bovine serum albumin in pigeons due to L-carnitine supplementation. $\mathrm{Br}$. Poult. Sci. 41, 448-453.

Jensen, C., Lauridsen, C. \& Bertelsen, G., 1998. Dietary vitamin E: Quality and storage stability of pork and poultry. Trends Food Sci. Technol. 9, 62-72.

Kalaiselvi, T. \& Panneerselvam, C., 1998. Effect of L-carnitine on the status of lipid peroxidation and antioxidants in aging rats. J. Nutr. Biochem. 9, 575-581.

Kidd, M.T., Mcdaniel, C.D., Peebles, E.D., Barber, S.J., Corzo, A., Branton, A.L. \& Woodworth, J.C., 2005. Breeder hen dietary L-carnitine affects progeny carcase traits. Br. Poult. Sci. 46, 97-103.

Kita, K., Kato, S., Yaman, M.A., Okumura, J. \& Yokota, H., 2002. Dietary L-carnitine increases plasma insulin-like growth factor-I concentration in chicks fed a diet with adequate dietary protein level. $\mathrm{Br}$. Poult. Sci. 43, 117-121.

Lauridsen, C., Buckley, D.J. \& Morrissey, P.A., 1997. Influence of dietary fat and vitamin E supplementation on $\alpha$-tocopherol levels and fatty acid profiles in chicken muscle membranal fractions and on susceptibility to lipid peroxidation. Meat Sci. 46, 9-22.

Lawlor, J.B., Sheehy, P.J.A., Kerry, J.P., Buckley, D.J. \& Morrissey, P.A., 1999. A note on the relationship between initial vitamin $\mathrm{E}$ content of four beef muscles and drip loss during refrigerated storage. Irish J. Agri. Food Res. 39, 261-266.

Lawlor, J.B., Sheehan, E.M., Delahunty, C.M., Morrissey, P.A. \& Kerry, J.P., 2003. Oxidative stability of cooked chicken breast burgers obtained from organic, free-range and conventionally reared animals. Int. J. Poult. Sci. 2 (6), 398-403.

Leibetseder, J., 1995. Studies of L-carnitine effects in poultry. Arch. Anim. Nutr. 48, 97-108.

Lettner, V.F., Zollitisch, W. \& Halbmayer, E., 1992. Supplementation of L-carnitine in broiler diets. Soilculture 43, 161-167.

Lien, T.F. \& Horng, Y.M., 2001. The effect of supplementary dietary L-carnitine on the growth performance, serum components, carcase traits and enzyme activities in relation to fatty acid and $\beta$-oxidation of broiler chickens. Br. Poult. Sci. 42, 92-95.

Lopez-Bote, C.J., Rey, A.I., Sanz, M., Gray, J.I. \& Buckley, D.J., 1997. Dietary vegetable oils and $\alpha$-tocopherol reduce lipid oxidation in rabbit muscle. J. Nutr. 127, 1176-1182.

Mast, J., Buyse, J. \& Goddeeris, B.M., 2000. Dietary L-carnitine supplementation increases antigen-specific immunoglobulin G production in broiler chickens. Br. J. Nutr. 83, 161-166.

Matalliotakis, I., Koumantaki, Y., Evageliou, A., Matalliotakis, G., Goumenou, A. \& Koumantakis, E., 2000. L-carnitine levels in the seminal plasma of fertile and infertile men: correlation with sperm quality. Int. J. Fertil. 45, 236-240.

Neuman, S.L., Lin, T.L. \& Hester, P.Y., 2002. The effect of dietary carnitine on semen traits of white leghorn roosters. Poult. Sci. 81, 495-503.

NRC, 1994. Nutrient Requirements of Domestic Animals. Nutrient Requirements of Poultry (9th ed). National Academy Press, Washington, D.C., USA.

O'Sullivan, C.M., Lynch, A.M., Lynch, P.B., Buckley, D.J. \& Kerry, J.P., 2004a. Assessment of the antioxidant potential of food ingredients in fresh, previously frozen and cooked chicken patties. Int. J. Poult. Sci. 3, 337-344.

O’Sullivan, C.M., Lynch, A.M., Lynch, P.B., Buckley, D.J. \& Kerry, J.P., 2004b. Use of antioxidants in chicken nuggets manufactured with and without the use of salt and/or sodium tripolyphoshate: effects on product quality and shelflife stability. Int. J. Poult. Sci. 3, 345-353.

Rabie, M.H. \& Szilagyi, M., 1998. Effects of L-carnitine supplementation of diet differing in energy levels on performance, abdominal fat content and yield and composition of edible meat of broilers. Br. J. Nutr. 80, 391-400.

Rabie, M.H., Szilagyi, M. \& Gippert, T., 1997a. Effects of dietary L-carnitine supplementation and protein level on performance and degree of meatness and fatness of broilers. Acta Biol. Hung. 48, 221-239. 
Rabie, M.H., Szilagyi, M., Gippert, T., Votisky, E. \& Gerendai, D., 1997b. Influence of dietary L-carnitine on performance and carcass quality of broiler chickens. Acta Biol. Hung. 48, 241-252.

Rani, P.J.A. \& Panneerselvam, C., 2002. Effect of L-carnitine on brain lipid peroxidation and antioxidant enzymes in old rats. J. Gerontology: Biol. Sci. 57, 134-137.

Rebouche, C.J., 1991. Ascorbic acid and carnitine biosynthesis. Am. J. Clin. Nutr. 54, 1147-1152.

Rebouche, C.J., 1992. Carnitine function and requirements during the life cycle. FASEB J. 6, 3379-3386.

Russell, E.A., Lynch, A., Galvin, K., Lynch, P.B. \& Kerry, J.P., 2003. Quality of raw, frozen and cooked duck meat as affected by dietary fat and $\alpha$-tocopherol acetate supplementation. Int. J. Poult. Sci. 2, 324-334.

Sarica, S., Corduk, M. \& Kilinc, K., 2005. The effect of dietary L-carnitine supplementation on growth performance, carcass traits and composition of edible meat in Japanese quail (Coturnix coturnix japonica). J. Appl. Poult. Res. 14, 709-715.

SPSSWIN, 1994. SPSS for Windows 6.1.3. SPSSWIN, Istanbul, Turkey.

Tarladgis, B.G., Watts, B.M., Younathan, M.T. \& Dudan Jr, L.R., 1960. A distillation method for the quantitative determination of malonaldehyde in rancid foods. JAOCS 37, 44-48.

WPSA. 1989. European table of energy values for poultry feedstuffs (3rd ed.). WPSA Subcommittee, Beekbergen. The Netherlands.

Xu, Z.R., Zhan, X.A. \& Mao, H.X., 2002. Effect of L-carnitine on fat metabolism in broilers. Chinese J. Anim. Sci. 38 (5), 20-22.

Xu, Z.R., Wang, M.Q., Mao, H.X., Zhan, X.A. \& Hu, C.H., 2003. Effects of L-carnitine on growth performance, carcass composition and metabolism of lipids in male broilers. Poult. Sci. 82, 408-413. 